\title{
The $\operatorname{cym} A$ Gene, Encoding a Tetraheme $c$-Type Cytochrome, Is Required for Arsenate Respiration in Shewanella Species ${ }^{\nabla}$
}

\author{
Julie N. Murphy and Chad W. Saltikov* \\ Department of Environmental Toxicology, University of California, Santa Cruz, Santa Cruz, California 95064
}

Received 2 November 2006/Accepted 21 December 2006

\begin{abstract}
In Shewanella sp. strain ANA-3, utilization of arsenate as a terminal electron acceptor is conferred by a two-gene operon, $\operatorname{arr} A B$, which lacks a gene encoding a membrane-anchoring subunit for the soluble ArrAB protein complex. Analysis of the genome sequence of Shewanella putrefaciens strain CN-32 showed that it also contained the same arr $A B$ operon with $100 \%$ nucleotide identity. Here, we report that $\mathrm{CN}-32$ respires arsenate and that this metabolism is dependent on arrA and an additional gene encoding a membrane-associated tetraheme $c$-type cytochrome, $\operatorname{cym} A$. Deletion of $\operatorname{cym} A$ in ANA-3 also eliminated growth on and reduction of arsenate. The $\Delta$ cym $A$ strains of $\mathrm{CN}-32$ and ANA-3 negatively affected the reduction of $\mathrm{Fe}$ (III) and $\mathrm{Mn}$ (IV) but not growth on nitrate. Unlike the CN-32 $\Delta$ cymA strain, growth on fumarate was absent in the $\Delta$ cymA strain of ANA-3. Both homologous and heterologous complementation of $\mathrm{cym} A$ in trans restored growth on arsenate in $\Delta$ cym $A$ strains of both CN-32 and ANA-3. Transcription patterns of cymA showed that it was induced under anaerobic conditions in the presence of fumarate and arsenate. Nitrate-grown cells exhibited the greatest level of cymA expression in both wild-type strains. Lastly, site-directed mutagenesis of the first Cys to Ser in each of the four CXXCH $c$-heme binding motifs of the $\mathrm{CN}-32$ CymA nearly eliminated growth on and reduction of arsenate. Together, these results indicate that the biochemical mechanism of arsenate respiration and reduction requires the interactions of ArrAB with a membrane-associated tetraheme cytochrome, which in the non-arsenate-respiring Shewanella species Shewanella oneidensis strain MR-1, has pleiotropic effects on Fe(III), Mn(IV), dimethyl sulfoxide, nitrate, nitrite, and fumarate respiration.
\end{abstract}

Metal-reducing bacteria can significantly impact the fate and transport of arsenic in sediments and groundwater $(2,10-12$, 35). Reduction of iron oxides containing arsenate $\left[\mathrm{HAsO}_{4}{ }^{2-}\right.$; $\mathrm{As}(\mathrm{V})]$ can liberate arsenite $\left[\mathrm{H}_{3} \mathrm{AsO}_{3} ; \mathrm{As}(\mathrm{III})\right]$ into porewaters, leading to the contamination of aquifers and groundwater (4). Arsenate reduction under these conditions is most likely due to $\mathrm{As}(\mathrm{V})$-respiring prokaryotes, which are known to be diverse and to utilize a variety of electron acceptors, including $\mathrm{Fe}$ (III) and Mn(IV) (hydr)oxides (17, 24, 25).

In the metal-reducing bacterium Shewanella sp. strain ANA-3, two genes, $\operatorname{arr} A$ and $\operatorname{arr} B$, are required for arsenate respiration (28). The gene products, ArrA, a $\sim 95-\mathrm{kDa}$ molybdenum-containing arsenate reductase subunit, and ArrB, an $\sim 26-\mathrm{kDa}$ Fe-S-containing subunit, are soluble and localized to the periplasm $(1,15,16)$. Based on several biochemical features (e.g., size, Mo cofactor, amino acid sequence similarity, and cofactor binding motifs), ArrA is part of a large family of molybdenum-containing oxidoreductases (e.g., dimethyl sulfoxide, nitrate, polysulfide, and trimethylamine $N$-oxide [TMAO] reductases) (18). Other prokaryotic molybdenum cofactorcontaining oxidoreductases employ a membrane protein, which serves as a site for anchoring the soluble Mo and Fe-S subunits to the cytoplasmic membrane (18). In some cases, the membrane-anchoring subunit also functions to transfer electrons from the quinone pool to the catalytic subunits (6). Several of these membrane-associated subunits have been shown

\footnotetext{
* Corresponding author. Mailing address: Department of Environmental Toxicology, University of California, Santa Cruz, Santa Cruz, CA 95064. Phone: (831) 459-5520. Fax: (831) 459-3524. E-mail: saltikov @etox.ucsc.edu.

${ }^{\nabla}$ Published ahead of print on 5 January 2007.
}

to be $c$-type cytochromes $(16,20,26)$. In the non-As(V)-respiring Shewanella species Shewanella oneidensis strain MR-1, a 21-kDa membrane-associated periplasmic $c$-type cytochrome, CymA, is required for respiration of fumarate, nitrate, $\mathrm{Fe}(\mathrm{III})$, dimethyl sulfoxide, and nitrite $(20,23,32)$. CymA is part of the NapC/NirT family of tetraheme cytochromes, which, unlike CymA, provide more specialized functions in other bacteria (20). For example, in Paracoccus denitrificans, the NapC protein transfers electrons from the quinols to the periplasmic nitrate reductase (26). In contrast to most members of the NapC/NirT tetraheme cytochromes, CymA acts as a common branching point in the electron transport chain of Shewanella species by serving as a redox intermediary between the quinone pool and multiple terminal reductases (32).

Because the arr operon of Shewanella sp. strain ANA-3 lacks a gene encoding a membrane subunit for ArrAB, it was predicted that CymA would be involved in the $\mathrm{As}(\mathrm{V})$ respiratory pathway in $\mathrm{As}(\mathrm{V})$-respiring Shewanella species. Here, we investigate the functional role of $\operatorname{cym} A$ in the $\mathrm{As}(\mathrm{V})$ respiratory reduction pathways of several Shewanella species.

\section{MATERIALS AND METHODS}

Strains and plasmids. All Escherichia coli and Shewanella strains and plasmids used in this study are described in Table 1. Shewanella sp. strain W3-18-1 was a kind gift from Jizhong Zhou at the University of Oklahoma.

Growth conditions. Standard culturing of ANA-3, CN-32, and E. coli strains was done in Luria-Bertani medium (31) or a minimal medium (described below). The ANA-3 and $\mathrm{CN}-32$ strains were grown at $30^{\circ} \mathrm{C}$, and liquid cultures were shaken at $250 \mathrm{rpm}$. Anaerobic culturing was done in a minimal medium (TME, $\mathrm{pH} 7$ ) consisting of $1.5 \mathrm{~g} \mathrm{liter}^{-1} \mathrm{NH}_{4} \mathrm{Cl}, 0.6 \mathrm{~g} \mathrm{liter}^{-1} \mathrm{NaHPO}_{4}, 0.1 \mathrm{~g} \mathrm{liter}^{-1} \mathrm{KCl}$, $0.5 \mathrm{~g} \mathrm{liter}^{-1}$ yeast extract, $10 \mathrm{mM}$ HEPES, $20 \mathrm{mM}$ lactate, and $10 \mathrm{ml}$ liter $^{-1}$ (each) trace mineral and vitamin solutions (13). The medium was boiled under a stream of $\mathrm{N}_{2}$, anaerobically dispensed into $\mathrm{N}_{2}$-flushed Balch tubes, sealed with 
TABLE 1. Bacterial strains and plasmids used in this study

\begin{tabular}{|c|c|c|}
\hline Strain or plasmid & Genotype or markers, characteristics, and uses & $\begin{array}{l}\text { Source or } \\
\text { reference }\end{array}$ \\
\hline \multicolumn{3}{|l|}{ E. coli strains } \\
\hline TOPO Top 10 & $\begin{array}{l}\text { E. coli host for cloning; } \mathrm{F}^{-} \text {mcrA } \Delta(\text { mrr-hsdRMS-mcrBC }) \phi 80 l a c \mathrm{Z} \Delta \mathrm{M} 15 \Delta \text { acX } 74 \text { recA1 } \\
\text { araD139 } \Delta \text { (ara-leu }) 7697 \text { galU galK rpsL }\left(\mathrm{Str}^{\mathrm{r}}\right) \text { endA1 nupG }\end{array}$ & Invitrogen \\
\hline UQ950 & $\begin{array}{l}\text { E. coli } \mathrm{DH} 5 \alpha \lambda \text { (pir) host for cloning; } \mathrm{F}^{-} \Delta(\operatorname{argF} \text {-lac }) 169 \phi 80 \text { dlacZ58(DM15) glnV44(AS) } \\
\text { rfbD1 gyrA96(NalR) recA1 endA1 spoT1 thi-1 hsdR17 deoR } \lambda \text { pir }^{+}\end{array}$ & 28 \\
\hline WM3064 & $\begin{array}{l}\text { Donor strain for conjugation; thrB1004 pro thi rpsL hsdS lacZDM15 RP4-1360 } \Delta(\text { araBAD }) 567 \\
\quad \Delta d a p A 1341::[\text { erm } \operatorname{pir}(\mathrm{wt})]\end{array}$ & 28 \\
\hline \multicolumn{3}{|l|}{ Shewanella strains } \\
\hline Shewanella sp. ANA-3 & $\begin{array}{l}\text { Isolated from an As-treated wooden pier piling in a brackish estuary (Eel Pond, Woods } \\
\text { Hole, MA) }\end{array}$ & 27 \\
\hline AN-CYMA & Shewanella sp. strain ANA-3; $\triangle c y m A$; does not respire $\mathrm{As}(\mathrm{V})$ or fumarate & This study \\
\hline S. putrefaciens $\mathrm{CN}-32$ & Isolated from anaerobic subsurface core sample, New Mexico & 8,34 \\
\hline CN-CYMA & S. putrefaciens $\mathrm{CN}-32 ; \Delta$ cym $A$; does not respire $\mathrm{As}(\mathrm{V})$ & This study \\
\hline Shewanella sp. W3-18-1 & Isolated from Pacific Ocean marine sediments at $630 \mathrm{~m}$ & 19 \\
\hline \multicolumn{3}{|l|}{ Plasmids/vectors } \\
\hline pCR4-TOPO & 4-kb cloning vector; $l a c Z-c c d B: \mathrm{Km}^{\mathrm{r}} A \mathrm{mp}^{\mathrm{r}}$ & Invitrogen \\
\hline pSMV10 & 9.1-kb mobilizable suicide vector; oriR6K mobRP4 $s a c B \mathrm{Km}^{\mathrm{r}} \mathrm{Gm}^{\mathrm{r}}$ & 28 \\
\hline $\mathrm{ANp} \Delta \operatorname{cym} A$ & $\begin{array}{l}\text { 1.2-kb fusion PCR fragment containing } \Delta \text { cym } A \text { from ANA-3 cloned into the SpeI site of } \\
\text { pSMV10; used to make the AN-CymA } \Delta c y m A \text { strain. }\end{array}$ & This study \\
\hline $\mathrm{CNp} \Delta$ cym $A$ & $\begin{array}{l}\text { 2-kb fusion PCR fragment containing } \Delta c y m A \text { from } S \text {. putrefaciens cloned into the SpeI site of } \\
\text { pSMV10; used to make the CN-CymA } \Delta \text { cym } A \text { strain. }\end{array}$ & This study \\
\hline pBBR1MCS-2 & 5.1-kb broad-host-range plasmid; $\mathrm{Km}^{\mathrm{r}}$ lac $Z$ & 14 \\
\hline pANcymA & $\begin{array}{l}\text { ANA-3 cymA PCR fragment, including the promoter region, cloned into the SpeI site of } \\
\text { pBBR1MCS-2 }\end{array}$ & This study \\
\hline $\mathrm{pCN} c y m A$ & S. putrefaciens cymA PCR fragment cloned into the SpeI sites of pBBR1MCS-2 & This study \\
\hline $\mathrm{pH} 1(\mathrm{C} 46 \mathrm{~S})$ & pCNcymA plasmid with SXXCH of heme 1 & This study \\
\hline $\mathrm{pH} 2(\mathrm{C} 78 \mathrm{~S})$ & pCNcymA plasmid with CXXSH of heme 2 & This study \\
\hline $\mathrm{pH} 3(\mathrm{C} 136 \mathrm{~S})$ & pCNcymA plasmid with SXXCH of heme 3 & This study \\
\hline $\mathrm{pH} 4(\mathrm{C} 173 \mathrm{~S})$ & pCNcymA plasmid with SXXCH of heme 4 & This study \\
\hline
\end{tabular}

butyl rubber stoppers, and autoclave sterilized. Media were supplemented with $10 \mathrm{mM}$ fumarate, nitrate, TMAO, or arsenate or $25 \mathrm{mM}$ hydrous ferrous oxide from sterile anaerobic stock solutions.

Growth experiments. Aerobic cultures were grown overnight in TME medium. The optical density (OD) at $600 \mathrm{~nm}$ of each culture was brought below 0.6 , and they were standardized to each other by the addition of TME medium to ensure that the inoculation levels for all strains were equal. The cells were then inoculated at $1 / 100$ dilution into anaerobic tubes. Growth was monitored by measuring the OD at $600 \mathrm{~nm}$ using a Spectronic 20. Control cultures were also grown and monitored in anaerobic TME without added electron acceptors.

The ferrozine assay was used to monitor Fe(III) reduction. Under anaerobic conditions, $50 \mu \mathrm{l}$ of cell culture was added to $450 \mu \mathrm{l} 0.5 \mathrm{M} \mathrm{HCl}$, mixed, and filtered through a $0.2-\mu \mathrm{m}$ filter (Spin-X column); $10 \mu \mathrm{l}$ of this mixture was then added to an additional $90 \mu \mathrm{l} 0.5 \mathrm{M} \mathrm{HCl}$ in a 96-well microtiter dish. Ferrozine solution (100 $\mu \mathrm{l}$ of $0.1 \%$ ferrozine dissolved in $50 \%$ [wt/vol] ammonium acetate solution) was added, and the absorbance at $540 \mathrm{~nm}$ was read after $10 \mathrm{~min}$. Sample absorbances were compared to standard curves of known ferrous chloride concentrations $[10,100$, and $500 \mu \mathrm{M} \mathrm{Fe}(\mathrm{II})]$ prepared in $\mathrm{HCl}$.

Some growth experiments also measured the level of oxidation of lactate to acetate and reduction of arsenate to arsenite. This was done by removing $0.5 \mathrm{ml}$ from each culture, filtering it through a $0.2-\mu \mathrm{m}$ filter (Spin-X column), and quantifying the sample by high-performance liquid chromatography as described previously (27). All growth experiments were done in triplicate.

Sequencing of ANA-3 cymA. The set of degenerate primers (CymA-F, 5'-TGG CGT GCA CTA TTY AAA CC-3', and CymA-R, 5'-TAR GGG TGA GCR ACR CCT TT-3') used to amplify the $c y m A$ gene in ANA-3 was designed by comparing the cymA sequences (with corresponding accession numbers in parentheses) in S. putrefaciens CN-32 (ZP_00815799), S. oneidensis MR-1 (NP_720107), S. amazonensis SB2B (ZP_00584682), S. frigidimarina (YP_748973), S. loihica PV4 (ZP 00837170), and S. baltica (ZP 00582221) using MacVector and selecting the regions of highest DNA similarity. The amplified product from ANA-3 genomic DNA was cloned into $E$. coli using the TA TOPO Cloning Kit (Invitrogen). Plasmids from three $\mathrm{Km}^{\mathrm{r}}$ colonies were sequenced using M13 primers. The resulting sequence was then used to design primers for inverse PCR and sequencing (ANAcymAiPCR-F1, 5'-AGA ACC AGC CAG ACA CTA TG-3', and ANAcymAiPCR-R1, 5'-GTG TGG TAA GTG GCA GTC TT-3') of BamHI-digested and self-ligated ANA-3 genomic DNA. This PCR product was cloned using the TA TOPO cloning kit, and the resulting plasmids were sequenced using ANAcymAiPCR-F1 and ANAcymAiPCR-R1. Primer walking and sequencing were done using the primers ANAcymAiPCR-F2, 5'-GCT GCA CGA GAA TAA TAG GT-3', and cymAiPCR-R2, 5'-TAA TAC GAC AAC TCG CTC AA-3'.

Mutagenesis. In-frame, nonpolar deletions of cymA were generated using previously developed methods (28) with primers X-CNcymA-A (5'-GGA CTA GTG TCA AAC CGC CAA AAA TAA A-3'), X-CNcymA-B (5'-[TGT TTA AGC ATG CTG GAT GGG] AAA GGA TAA TAG GTT TTA GCG-3'), X-CNcymA-C (5'-[CCC ATC CAG CAT GCT TAA ACA] CCA GTT CAT TAC TCT ATC TCC-3'), and X-CNcymA-D (5'-GGA CTA GTC TGA CGA TAA GGC ACC ACA A-3') for cym $A$ in CN32 and X-ANAcym $A$-A (5'-GGA CTA GTG TGT ACC TGT TCC TAA AGA CC-3'), X-ANAcymA-B (5'-[CCC ATC CAG CAT GCT TAA ACA] CCA GTT CAT CAC TCT ATC TCC-3' ${ }^{\prime}$, X-ANAcymA-C (5'-[TGT TTA AGC ATG CTG GAT GGG] AAA GGA TAA GGT TTA GCG CTT-3'), and X-ANAcymA-D (5'-GGA CTA GTG ATA CGA CTC AGG GTG AG GT-3') for cymA in ANA-3 (SpeI sites are underlined; the bracketed areas are the 21-bp PCR linkers, with SphI sites underlined). Because of the limited sequence data at the time of this work, two $\sim 400$-bp DNA fragments flanking the cymA gene were amplified (the complete ANA-3 genome sequence is now available).

The complementation plasmids pCNcymA and pANcymA were generated by cloning PCR products of the CN-32 and ANA-3 cymA genes into the SpeI site of pBBR1MCS-2. The following primers were used to generate the genes: $\mathrm{CNcymA}$ comp-F1 (5'-GGA CTA GTG TTT ATC GTC AGC GAG TGA T-3'), CNcymA comp-R1 (5'-GGA CTA GTT GGC AAT TTT GGA GAT AGA G-3'), AN cymA comp-F1 (5'-GGA CTA GTG GAG ATA GAG TGA TGA ACT GG-3'), and ANcymAcomp-R1 (5'-GGA CTA GTC AAG CAT TTA CTG TTA TGT GG-3') (SpeI sites are underlined). Transformation of the complementation 
vectors into Shewanella sp. strain ANA-3 and CN-32 was performed as previously described (28).

Mutations to the heme binding regions in CN-32 cymA were generated using the following modified protocol of the QuikChange Site-Directed Mutagenesis method (Stratagene). Primers CNcymAheme-F1 (5'-T ACG GAT CAG TTC agc ATG TCC TGT CAC A-3'), CNcymAheme-F2 (5'-ACC GTT CAA TGT CAA GAC agc CAC TTA CCA CA-3'), CNcymAheme-F3 (5'-AAT GAC TCC GCT AAC agc CAA CAC TGC CAT ACT-3'), and CNcymAheme-F4 (5'-GAA GCC AGA AAA ACC agc GTT GAC TGC CAT AAA-3') were designed with a cysteine-to-serine substitution (in lowercase); the primers are numbered $\mathrm{F} 1$ to F4 to correspond to hemes 1 to 4 , respectively. Each heme motif was mutated separately in 25- $\mu$ l reaction mixtures containing $2.5 \mu \mathrm{l} 10 \times P f u$-Turbo Hotstart Buffer (Strategene), $0.2 \mathrm{mM}$ deoxynucleoside triphosphate mix, $125 \mathrm{ng}$ primer, $50 \mathrm{ng}$ pCNcymA plasmid, $1 \mu \mathrm{l} P f u$-Turbo Hotstart DNA polymerase (Stratagene), and nuclease-free water. Samples were incubated with the following cycle profile: $95^{\circ} \mathrm{C}$ for $30 \mathrm{~s}$ and 18 cycles of $95^{\circ} \mathrm{C}$ for $30 \mathrm{~s}, 55^{\circ} \mathrm{C}$ for $1 \mathrm{~min}$, and $68^{\circ} \mathrm{C}$ for $11 \mathrm{~min}$. The reaction mixtures were cooled to room temperature, and $1 \mu \mathrm{l} \mathrm{DpnI}$ (10 units) was added to each reaction mixture and incubated for $1 \mathrm{~h}$ at $37^{\circ} \mathrm{C}$. Each reaction mixture was transformed into a DH5 $\alpha-\lambda$ pir strain (UQ950) (28). Plasmids were extracted and sequenced to confirm the correct mutation. The resulting heme-mutated $\mathrm{pCN} c y m A$ vectors were then transformed into $\mathrm{CN}$ CYMA by conjugation as previously described. The plasmid strains were denoted $\mathrm{pH}$ 1(C46S), $\mathrm{pH}$ 2(C78S), $\mathrm{pH} 3(\mathrm{C} 136 \mathrm{~S})$, and $\mathrm{pH} 4(\mathrm{C} 173 \mathrm{~S})$ for mutations in the heme 1 through the heme 4 motif, respectively.

Quantification of cymA transcription. The methods for quantitative reverse transcription-PCR have been described previously (29). ANA-3 cells were grown anaerobically in triplicate $10-\mathrm{ml}$ TME cultures amended with $10 \mathrm{mM}$ nitrate, 10 $\mathrm{mM}$ fumarate, or $10 \mathrm{mM}$ As(V). Aerobically prepared cells were grown in $15 \mathrm{ml}$ TME in 250-ml flasks with constant sparging of filtered air. Cells were harvested in mid-exponential growth phase (OD at $600 \mathrm{~nm}, 0.1$ ). One milliliter of the cultures was centrifuged at $14,000 \mathrm{rpm}$ at $4^{\circ} \mathrm{C}$ for $10 \mathrm{~min}$. The cell pellets were stored at $-80^{\circ} \mathrm{C}$ until further analysis was performed. RNA was extracted from the cell pellets using the QIAGEN RNeasy miniprep kit according to the manufacturer's instructions, with a final elution volume of $40 \mu \mathrm{l}$. DNA contamination was removed by DNase (Promega RQ1 DNase) digestion. cDNA was synthesized as described previously (29).

The real-time PCRs $(30 \mu \mathrm{l})$ consisted of $15 \mu \mathrm{l} 2 \times$ SybrGreen Taq Mix (Applied Biosystems), $300 \mathrm{nM}$ of primers q-ANAcymA-F1 (5'-GAG AAC CAG CCA GAC ACT AT-3') and q-ANAcymA-R1 (5'-ACA ATC CAC ACA GGT CTT TC- $3^{\prime}$ ), and $4 \mu \mathrm{l}$ RNA sample diluted $1 / 4$ in nuclease-free water. Each sample was run in duplicate using the MJ Research Opticon2. The thermocycle profile consisted of $95^{\circ} \mathrm{C}$ for $10 \mathrm{~min}, 40$ cycles of $95^{\circ} \mathrm{C}$ for $30 \mathrm{~s}$ and $60^{\circ} \mathrm{C}$ for $1 \mathrm{~min}$, and a final denaturing cycle to examine the DNA melting curves of PCR products.

The cycle threshold was calculated for each sample and converted to a DNA nanogram equivalent by comparing the cycle threshold values to a standard curve of known ANA-3 genomic DNA concentrations $(1,0.1,0.01,0.001$, and 0.0001 $\mathrm{ng}$ ), which had a slope of 3.6 and an $R^{2}$ (calculated from a linear regression of the data points) of 0.999 . The resulting DNA concentrations were normalized to the original amount of RNA template in each sample.

\section{RESULTS}

Shewanella putrefaciens strain CN-32 grows on arsenate. Sequence analysis of the recently completed genome of Shewanella putrefaciens strain $\mathrm{CN}-32$ showed that it contained an $\operatorname{arr} A B$ gene cluster that was identical to the $\operatorname{arr} A B$ of Shewanella sp. strain ANA-3. Moreover, the CN-32 arr-containing contig 160 was $100 \%$ identical to a $20-\mathrm{kb}$ region of the ANA-3 genome sequence containing $\operatorname{arr} A B$. We observed a similar genome structure in Shewanella sp. strain W3-18-1 contig 292; however, the region had numerous base pair differences ( $83 \%$ over $\sim 8 \mathrm{~kb}$ ). Neither $\mathrm{CN}-32$ nor W3-18-1 has been shown to respire $\mathrm{As}(\mathrm{V})$, and we were interested in testing whether these strains could use arsenate as an electron acceptor. Figure 1 shows the growth curve of $\mathrm{CN}-32$ in anaerobic medium containing arsenate. Growth reached stationary phase after $10 \mathrm{~h}$ of incubation. Analysis of substrates and products in culture filtrates collected during early- and mid-log and sta-

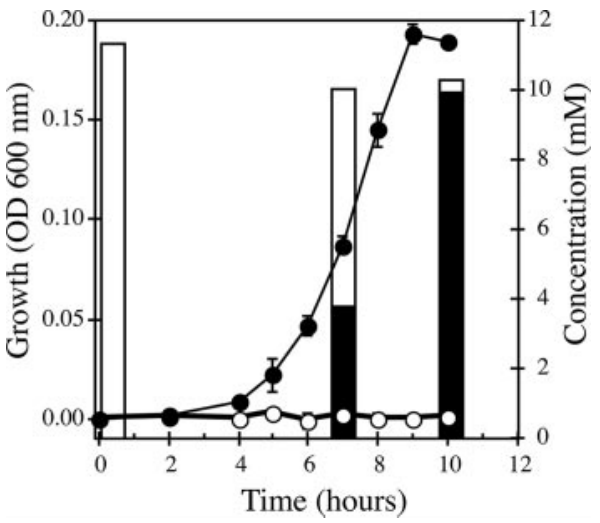

FIG. 1. Growth on arsenate $(10 \mathrm{mM})$ and reduction to arsenite by Shewanella putrafaciens strain $\mathrm{CN}-32$. $\bigcirc$, arrA null mutant; $\bullet$, wild type; open bars, arsenite; dark bars, arsenate. The data points and error bars represent the means and standard deviations of triplicate cultures, respectively.

tionary phases of growth confirmed that all $\mathrm{As}(\mathrm{V})$ was reduced to $\mathrm{As}$ (III) (Fig. 1), with nearly 2:1 molar stoichiometry of $\mathrm{As}(\mathrm{V})$ reduction compared to lactate oxidation. All the As(V) (11 $\mathrm{mM}$ ) was reduced to As(III), while $\sim 6 \mathrm{mM}$ lactate was oxidized to acetate $(\sim 4 \mathrm{mM}$ final concentration). These results are consistent with previous growth studies with ANA-3 (27). We confirmed the involvement of arr $A$ in arsenate respiration by generating an arr $A$ null mutation in CN-32. Growth on arsenate was eliminated but could be restored by complementation of the wild-type arr $A$ gene in trans to the $\mathrm{CN}-32$ arr $A$ null mutant (data not shown). Strain W3-18-1 also grew with arsenate as a terminal electron acceptor (data not shown). Based on these observations, we concluded that both ANA-3 and $\mathrm{CN}-32$, and most likely $\mathrm{W} 3-18-1$, respire arsenate via very similar mechanisms.

Identification of $\operatorname{cym} \boldsymbol{A}$ in ANA-3. Based on genome sequence data in other arsenate-respiring bacteria (e.g.., Desulfitobacterium hafniense and Wolinella succinogenes), their arr operons contain a third gene, $\operatorname{arr} C$, which encodes a putative membrane protein that most likely anchors the ArrAB to the cytoplasmic membrane. However, in the ANA-3, CN-32, and W3-18-1 genomes, no ArrC gene homologs were found. We hypothesized that CymA, a membrane-bound tetraheme $c$-type cytochrome, would be required for utilization of arsenate as a terminal electron acceptor in arsenate-respiring Shewanella. This predication was based on several studies that demonstrated that cym $A$ was required for anaerobic respiration of many electron acceptors in Shewanella oneidensis strain MR-1 (20, 32).

We obtained the sequence of ANA-3 cymA prior to the recent release of the full genome sequence of ANA-3. PCR primers were designed from conserved regions of DNA multisequence alignments of cym $A$ homologs found in other Shewanella genomes. The consensus primers generated an $\sim 500$-bp PCR product, which was sequenced. The predicted protein exhibited a high degree of similarity to other CymAs from various Shewanella species and was $100 \%$ identical to the CymA found in the ANA-3 genome sequence that is now available. Figure 2 illustrates the phylogenetic relationship of CymAs and other members of the NapC/NirT family tetraheme cytochromes. Shewanella CymAs were highly conserved 


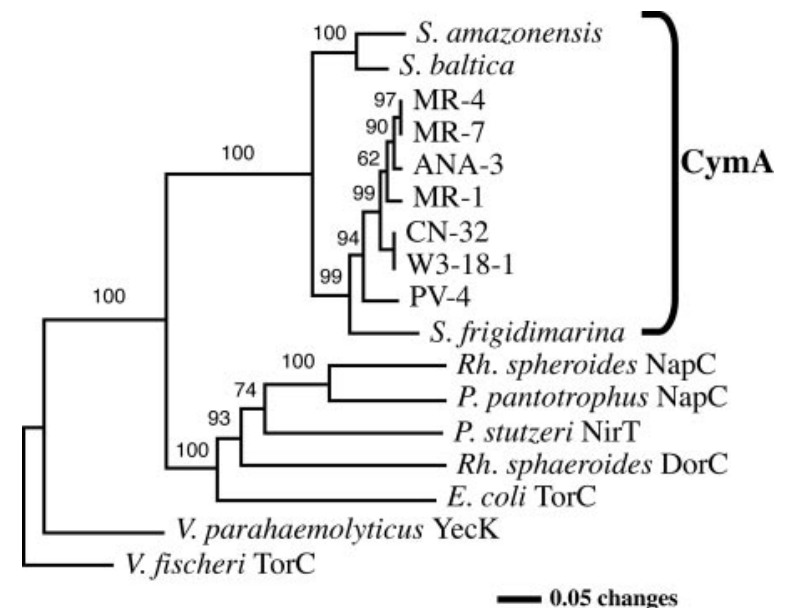

FIG. 2. Phylogenetic analysis of CymA using distance analysis (neighbor joining). The analysis included CymAs of various Shewanella species and selected tetraheme cytochromes within the NirT/NapC family. Bootstrap values are labeled at nodes with $\geq 50 \%$ occurrences. Accession numbers are as follows: Shewanella oneidensis MR-1, NP 720107; Shewanella sp. strain ANA-3, ZP 00849215; Shewanella sp. strain MR-4, YP_735897; Shewanella sp. strain MR-7, ABI40840; Shewanella putrefaciens CN-32, ZP 00815799; Shewanella sp. strain W3-18-1, ZP_00905699; Shewanella sp. strain PV-4, ZP_00837170; Shewanella frìidimarina, YP 748973; Shewanella amazonensis, ZP 00584682; Shewanella balticā, ZP_00582221; Pseudomonas stutzeri, TP24038; Vibrio fischeri, YP 206147; Vibrio parahaemolyticus, Q53178; Paracoccus pantotrophus, Q556352; E. coli, P33226; Rhodobacter sphaeroides, AAB94872; Vibrio parahaemolyticus, NP_799637.

and formed a distinct cluster within the tree of the tetraheme cytochrome family.

Physiological effects of deleting cym $A$. Because cymA has such a diverse roll in the respiration pathways of $S$. oneidensis, we predicted that similar roles for cym $A$ would be observed in both ANA-3 and CN-32 and in arsenate respiration. To test this prediction, we constructed nonpolar deletions of the cymA gene in ANA-3 and CN-32. To generate a cymA null mutant in ANA-3, additional DNA flanking the $\operatorname{cym} A$ gene was sequenced from an inverse PCR product of a genome fragment containing the cymA gene. This was not necessary for $\mathrm{CN}-32$, because the genome sequence was available at the time of this study. Strains lacking cymA were grown anaerobically on a variety of electron acceptors. The results are summarized in Table 2. Compared to wild-type strains of ANA-3 and CN-32 that normally reach stationary phase within $10 \mathrm{~h}$, neither deletion strain was able to grow when $\mathrm{As}(\mathrm{V})$ was added as an electron acceptor (Fig. 3A and B). Additionally, AN-CYMA was unable to respire fumarate; however, CN-CYMA showed growth on fumarate similar to that of the wild-type strain when grown under similar conditions. No growth defects were observed in AN-CYMA compared to the wild type when grown on TMAO. The wild-type CN-32 did not utilize TMAO as an electron acceptor. To confirm that the phenotypes of the cym $A$ null mutants were due to the loss of $\operatorname{cym} A$, both deletion strains, CN-CYMA and AN-CYMA, were complemented in trans with pCNcymA (Fig. 4A) or pANcymA (Fig. 4B), respectively. When grown anaerobically on the same substrates, the complemented strains regained the ability to respire $\mathrm{As}(\mathrm{V})$. Moreover, heterologous complementation of $\mathrm{pCNcymA}$ in
TABLE 2. Growth characteristics of AN-CYMA and CN-CYMA on known terminal electron acceptors

\begin{tabular}{|c|c|c|c|c|c|c|}
\hline \multirow{3}{*}{ Substrate } & \multicolumn{6}{|c|}{ Growth $^{a}$} \\
\hline & \multicolumn{2}{|c|}{ ANA-3 } & \multicolumn{2}{|c|}{$\mathrm{CN}-32$} & \multicolumn{2}{|c|}{$\mathrm{MR}-1^{b}$} \\
\hline & $\Delta c y m A$ & Wild type & $\Delta c y m A$ & Wild type & $\overline{\Delta c y m A}$ & Wild type \\
\hline Arsenate & - & + & - & + & - & - \\
\hline Fumarate & - & + & + & + & - & + \\
\hline DMSO & - & - & ND & ND & - & + \\
\hline Nitrate & + & + & + & + & - & + \\
\hline TMAO & + & + & - & - & + & + \\
\hline Thiosulfate & + & + & + & + & + & + \\
\hline Oxygen & + & + & + & + & + & + \\
\hline Fe(III) & - & + & - & + & - & + \\
\hline Mn(IV) & - & + & - & + & - & + \\
\hline
\end{tabular}

${ }^{a}$ Plus indicates growth on or reduction [Fe(III) and $\left.\mathrm{Mn}(\mathrm{IV})\right]$ of the substrate similar to the wild type. Minus indicates lack of growth on the corresponding substrate. Lactate $(20 \mathrm{mM})$ served as the electron donor and carbon source. Terminal electron acceptors were included in the anaerobic medium at $10 \mathrm{mM}$ ND, not determined.

${ }^{b}$ Sources, references 20 and 32

AN-CYMA and pANcymA in CN-CYMA showed full recovery of growth on all substrates. Strains harboring only the vector (pBBR1MCS-2) exhibited the same growth characteristics as their respective genetic backgrounds without the vector. These results provide evidence that $\operatorname{cym} A$ is essential to arsenate respiration and support the role of CymA as a uni-
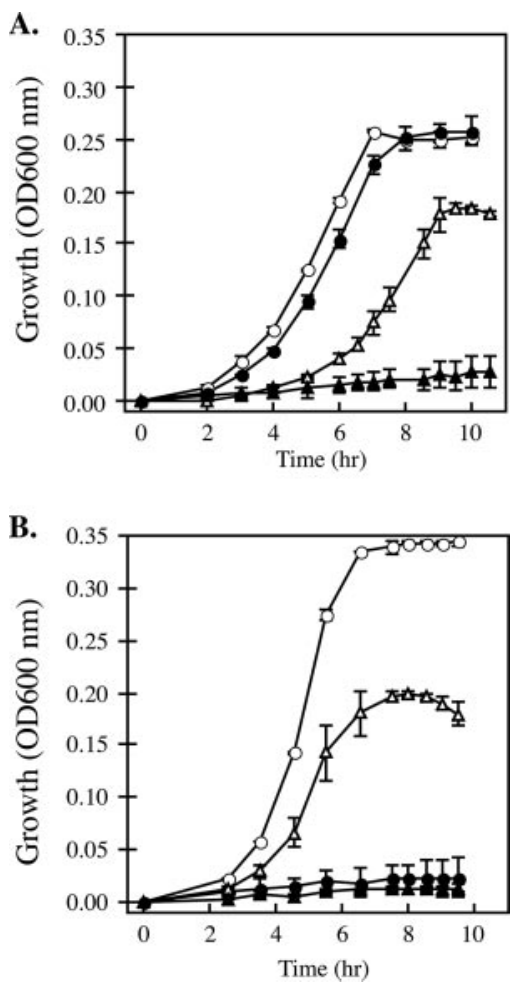

FIG. 3. Anaerobic growth on arsenate or fumarate of wild-type and cymA null mutant $(\Delta$ cym $A$ ) (A) Shewanella putrafaciens strain CN-32 and CN-CYMA and (B) Shewanella sp. strain ANA-3 and AN-CYMA, respectively. The time course for growth was inferred from the optical density at $600 \mathrm{~nm}$. $\bullet, \triangle$ cym $A$ grown on fumarate; $\bigcirc$, wild type grown on fumarate; $\boldsymbol{\Delta}, \triangle$ cymA grown on arsenate; $\triangle$, wild-type grown on arsenate. The data points and error bars represent the means and standard deviations of triplicate cultures, respectively. 

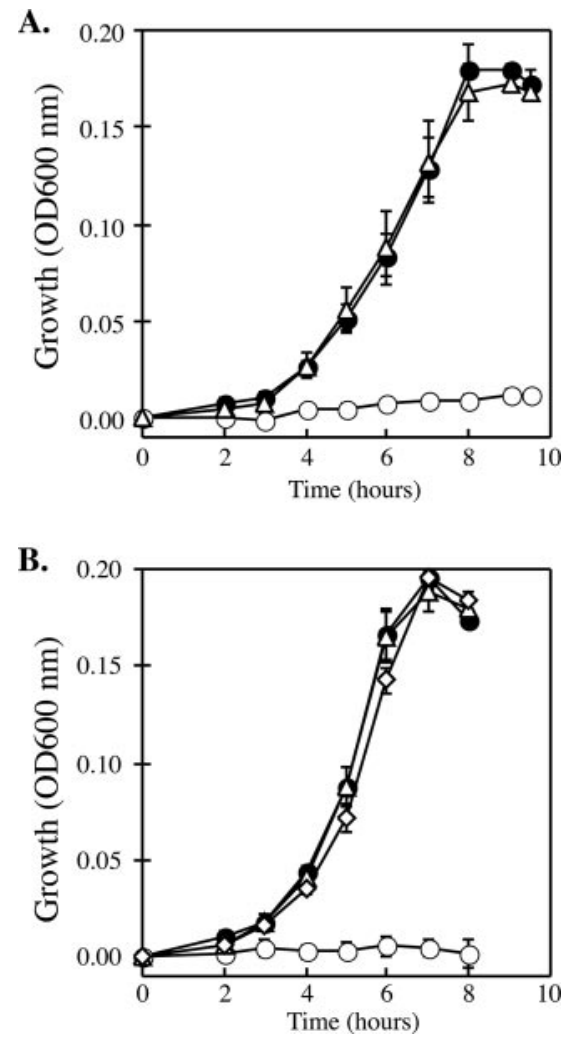

FIG. 4. Restoration of growth on arsenate $(10 \mathrm{mM})$ of Shewanella (A) $\mathrm{CN}-32$ and (B) ANA-3 cymA null mutants $(\Delta c y m A)$. The time course for growth was inferred from the optical density at $600 \mathrm{~nm}$. wild-type strain; $\bigcirc \triangle$ cymA null mutant with the vector (pBBR1MCS2); $\triangle, \triangle \operatorname{cym} A$ null mutant with $\operatorname{cym} A$ on a plasmid; $\diamond$, heterologous complementation of AN-CYMA $(\Delta \operatorname{cym} A)$ with $\mathrm{pCN} c y m A$. The data points and error bars represent the means and standard deviations of triplicate cultures, respectively.

versal redox mediator to various terminal electron acceptors in Shewanella.

cym $A$ transcription patterns. Having established that cym $A$ is necessary for respiration of $\mathrm{As}(\mathrm{V})$ and fumarate (ANA-3 only), we investigated various growth conditions that would most likely affect the transcription of $c y m A$ in ANA-3 and $\mathrm{CN}-32$. Total RNA was extracted from cultures grown to midlog phase (OD at $600 \mathrm{~nm}, 0.1$ ) on oxygen (vigorously sparged with air) and anaerobically with nitrate, fumarate, or As(V) as the terminal electron acceptor. cym $A$ expression was higher in cells grown anaerobically than in cells grown aerobically (Fig. 5 ). When anaerobic growth conditions were compared, cym $A$ expression was greater in samples grown in nitrate than in samples grown on fumarate or $\mathrm{As}(\mathrm{V})$. It was concluded that $\operatorname{cym} A$ expression is regulated on several levels, first by oxygen and secondly by the presence of specific terminal electron acceptors, mainly nitrate.

Mutations in heme motifs and their effects on arsenate respiration. The mechanism of electron transfer from CymA to terminal reductases is unknown. Presumably, redox reactions involve electron transfer from heme cofactors to other redox mediators in the terminal reductases (e.g., Fe-S clusters or Mo cofactor). To further understand this mechanism, we investigated the role of each heme cofactor in growth on and

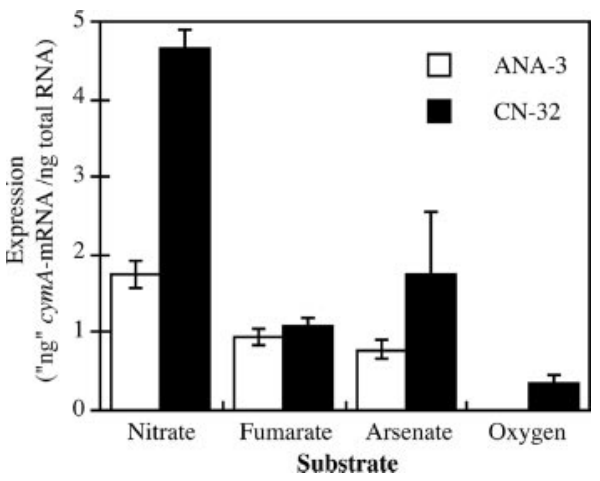

FIG. 5. Effects of different electron acceptors on cymA transcription in Shewanella putrefaciens strain CN-32 and Shewanella sp. strain ANA-3. CN-32 and ANA-3 were grown on different electron acceptors to the mid-exponential phase of growth (OD at $600 \mathrm{~nm}, 0.1)$. The nanogram genomic equivalent of mRNA for $c y m A$ was normalized to the total RNA used in the cDNA reaction. The data points and error bars represent the means and standard deviations of triplicate cultures, respectively.

reduction of arsenate. Four cym $A$ alleles were generated by site-directed mutagenesis of one of the cysteine residues in the four $\mathrm{CXXCH}$ motifs. These were replaced with a codon encoding serine (Fig. 6A). The four plasmids containing different Cys-to-Ser mutations were transformed into CN-CYMA, and growth and reduction of arsenate were monitored over time. Growth and reduction of arsenate were affected to varying degrees in each mutant cymA strain (Fig. 6B). Wild-type $\mathrm{CN}-32$ cultures containing only the vector reached stationary phase within $9 \mathrm{~h}$, while CN-CYMA carrying various cymA heme mutations exhibited little growth during that time. During extended incubation, growth was observed in the heme variants at a reduced capacity compared to the wild type (Fig. 6B). Mutations in Cys-46 to Ser [pH 1(C46S)] had the least effect on growth compared to the other the three Cys-to-Ser mutations. The strain carrying this heme variant had a lower growth rate than the wild-type $\operatorname{cym} A$; however, it eventually reached stationary phase by $28 \mathrm{~h}$. The three other Cys-to-Ser mutations resulted in dramatically lower growth rates and decreased OD at $600 \mathrm{~nm}$ in stationary-phase growth. By the end of the $52 \mathrm{~h}$, some growth was detected in $\mathrm{CN}-\mathrm{CYMA}+\mathrm{pH}$ 4(C173S), CN-CYMA+pBBR1MCS-2, CN-CYMA+pH 2(C78S), and $\mathrm{CN}-\mathrm{CYMA}+\mathrm{pH} 3(\mathrm{C} 136 \mathrm{~S})$. Reduction of arsenic occurred rapidly over the course of $10 \mathrm{~h}$ in $\mathrm{CN}$-CYMA with a wild-type cymA gene. However, in the CN-CYMA strains harboring the various $c y m A$ heme mutations, arsenate reduction was considerably less than in the wild-type cymA plasmid strain (Table 3 ).

\section{DISCUSSION}

Previous work with Shewanella sp. strain ANA-3 showed that arsenate respiration was conferred by $\operatorname{arr} A$ and $\operatorname{arr} B$ (28). The recent identification of $\operatorname{arr} A B$ operons in the genome sequences of two other Shewanella species strains, strains CN-32 and W3-18-1, suggested that these species should also respire arsenate, which should also be conferred by the arr operon. This was confirmed in $\mathrm{CN}-32$ by deleting $\operatorname{arr} A$, which eliminated growth on and reduction of arsenate (Fig. 1). Shewanella sp. strain W3-18-1 was also able to utilize arsenate 
A.

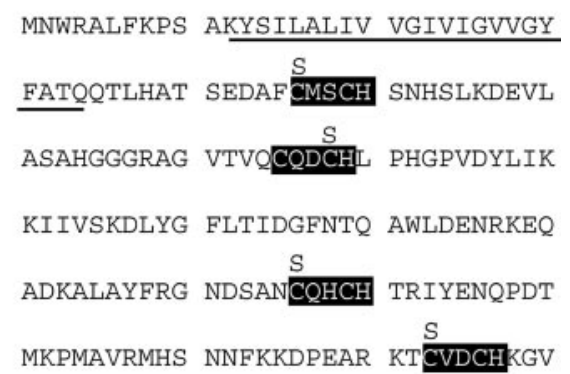

AHPYPKG

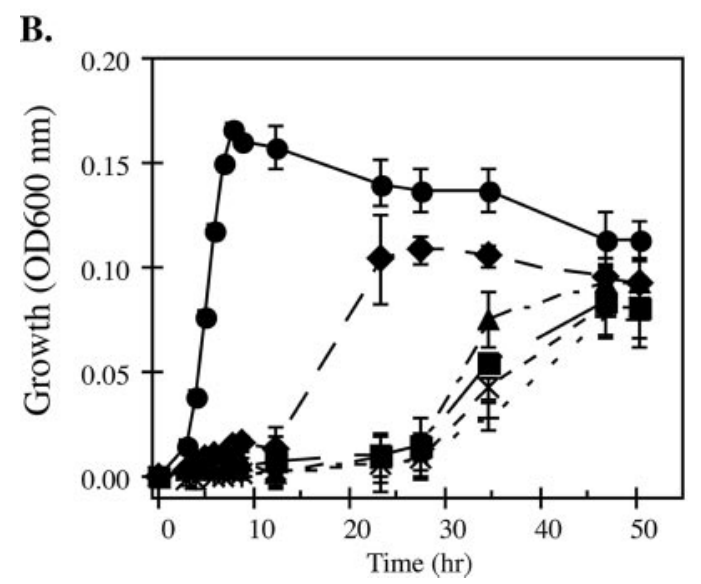

FIG. 6. The locations of heme motifs, cysteine-to-serine substitutions, and the predicted alpha helix membrane-anchoring domain (underlined) in CymA (A) and growth on arsenate of four cym $A$ heme mutants containing single cysteine-to-serine substitutions (B). The time course for growth was inferred from the optical density at $600 \mathrm{~nm}$. - $\mathrm{CN}-32$ plus vector; $\mathbf{\square}$, CN-CYMA plus vector; $\bullet, \mathrm{pH} 1(\mathrm{C} 46 \mathrm{~S})$; $\times$, $\mathrm{pH} 2(\mathrm{C} 78 \mathrm{~S}) ;+, \mathrm{pH} 3(\mathrm{C} 136 \mathrm{~S}) ; \boldsymbol{\Delta}, \mathrm{pH} 4(\mathrm{C} 173 \mathrm{~S})$. The data points and error bars represent the means and standard deviations of triplicate cultures, respectively.

(data not shown) as an electron acceptor, and it is predicted that deleting its arr $A$ homolog would eliminate growth on arsenate.

One striking feature of the Shewanella arr operon is the lack of a gene encoding a membrane-anchoring subunit for ArrAB, "ArrC"; evidence for an ArrC is present in the genomes of several bacteria that contain arr genes (e.g., Wolinella succinogenes [locus tag, WS0763; accession no. NP_906979] and Desulfitobacterium hafniense strain DCB-2 [locus tag, Dhaf_0249; accession no. ZP_01372403]). This observation raised questions about how the soluble arsenate respiratory reductase, ArrAB, interacts with components of the electron transport chain. In Shewanella, this interaction is most likely mediated by the tetraheme $c$-type cytochrome CymA, which is tethered to the membrane by an N-terminal alpha helix (Fig. 6A). This conclusion is supported by gene deletion and complementation of $\operatorname{cym} A$ in two arsenate-respiring Shewanella strains, CN-32 and ANA-3 (Fig. 3 and 4). Null mutations of $c y m A$ showed that this gene was necessary for $\mathrm{As}(\mathrm{V})$ respiration. Heterologous complementation of the ANA-3 cymA null mutant with a $\mathrm{CN}-32$ wild-type cym $A$ gene (and vice versa) restored utilization of arsenate as a terminal electron acceptor in these strains.
This observation is not surprising, because the genes are nearly identical; the nucleotide identity is $\sim 90 \%$ between the two cymA genes.

Consistent with previous studies of $\operatorname{cym} A(20,23,32)$, the substrate utilization patterns of Shewanella cymA null mutants exhibited pleiotropic effects on $\mathrm{Fe}(\mathrm{III})$ and $\mathrm{Mn}(\mathrm{IV})$ reduction (Table 2). However, deficiencies in fumarate and nitrate utilization differed among various Shewanella cymA null mutants (Table 2). Unlike in ANA-3 and MR-1, deleting cymA in $\mathrm{CN}-32$ did not affect its growth on fumarate. A similar pattern was observed for nitrate respiration. ANA-3 and CN-32 cymA null mutant strains were capable of growing on nitrate; in contrast, MR-1 cymA null mutants cannot respire nitrate (23). A Blast search for the periplasmic nitrate reductase Nap showed that the CN-32, ANA-3, and W3-18-1 genomes contain two nap loci, whereas MR-1 had only one. This additional nap locus may not involve CymA as an intermediate electron carrier for that particular nitrate reductase. In MR-1, deletion of cymA also resulted in an inability to grow on fumarate (23), but this effect was not observed in CN-32. Additional genome analyses of ANA-3, CN-32, MR-1, and W3-18-1 revealed that CN-32 and W3-18-1 contain additional orthologs of fumarate reductases/succinate dehydrogenases, unlike ANA-3 and MR-1. Similar to the additional nap locus in several Shewanella, it is likely that reduction of fumarate by one of these additional fumarate reductases may not involve CymA.

Because cym $A$ is required for growth on arsenate and other terminal electron acceptors, we investigated the environmental conditions that affected its expression. Previous studies had shown that the CymA protein, along with a number of other heme-containing proteins, was present in Shewanella membranes isolated under anaerobic growth conditions (7, 21-23). Quantification of cymA gene expression in ANA-3 confirmed that $\operatorname{cym} A$ was induced under anaerobic conditions (Fig. 5). The transcription patterns suggest that $\operatorname{cym} A$ is regulated in response to several environmental signals; oxygen, which causes repression; and the availability of specific electron acceptors, leading to induction. cym $A$ mRNA was most abundant

TABLE 3. Physiological effects of $S$. putrefaciens $\mathrm{CN}-32$ with cymA heme variants on the reduction of arsenate ${ }^{a}$

\begin{tabular}{lccr}
\hline \multicolumn{1}{c}{ Strain } & Time $(\mathrm{h})$ & $\begin{array}{c}\text { Arsenate } \\
(\mathrm{mM})\end{array}$ & $\begin{array}{c}\text { Arsenite } \\
(\mathrm{mM})\end{array}$ \\
\hline All & 0 & $9.9 \pm 0.22$ & $0.23 \pm 0.32$ \\
$\mathrm{CN}-32+$ pBBR1MCS-2 & 12.5 & $0.7 \pm 0.11$ & $9.7 \pm 0.00$ \\
& 50.5 & 0 & $9.7 \pm 0.06$ \\
$\mathrm{CN}-\mathrm{CYMA}+$ pBBR1MCS-2 & 12.5 & $9.7 \pm 0.14$ & $0.12 \pm 0.16$ \\
& 50.5 & $1.4 \pm 0.21$ & $8.6 \pm 0.01$ \\
$\mathrm{CN}-\mathrm{CYMA}+$ pH 1(C46S) & 12.5 & $9.2 \pm 0.30$ & $1.0 \pm 0.27$ \\
& 27.5 & 0 & $10.2 \pm 0.50$ \\
$\mathrm{CN}-\mathrm{CYMA}+$ pH 2(C78S) & 50.5 & 0 & $9.8 \pm 0.26$ \\
& 12.5 & $10.1 \pm 0.12$ & $0.10 \pm 0.12$ \\
$\mathrm{CN}-\mathrm{CYMA}+$ pH 3(C136S) & 50.5 & $1.5 \pm 0.21$ & $8.1 \pm 0.13$ \\
& 12.5 & $9.8 \pm 0.03$ & $0.18 \pm 0.16$ \\
$\mathrm{CN}-\mathrm{CYMA}+$ pH 4(C173S) & 50.5 & $2.5 \pm 0.36$ & $7.2 \pm 0.11$ \\
& 12.5 & $9.9 \pm 0.22$ & $0.07 \pm 0.05$ \\
& 50.5 & $1.4 \pm 1.98$ & $9.9 \pm 0.61$ \\
\hline
\end{tabular}

${ }^{a}$ The cultures represented in Fig. 6B were sampled at the indicated times, and the filtrates were analyzed by high-performance liquid chromatography for arsenate and arsenite. The data and errors represent the means and standard deviations of triplicate cultures, respectively. 
in nitrate-grown cells of ANA-3 and CN-32, even though cymA is not essential to nitrate reduction in these strains.

The functional roles of the four hemes of CymA were addressed by examining the involvement of each heme group in arsenate respiration (Fig. 6). It was hypothesized that mutations in any of the four hemes would significantly alter arsenate respiration in Shewanella. One of the cysteines of the $\mathrm{CXXCH}$ heme $c$ binding motif was changed to serine. In each of the single heme mutations, growth on arsenate was significantly diminished but not entirely eliminated. We observed an increased lag in growth on arsenate $(\sim 25 \mathrm{~h})$ if the mutations occurred in the three distal $\mathrm{CXXCH}$ motifs nearest the $\mathrm{C}$ terminus of CymA. A mutation in the first $\mathrm{CXXCH}$ motif (heme 1) resulted in the least severe growth defect on arsenate (an 12-h lag) (Fig. 6B). Mutational studies with the $\mathrm{CXXCH}$ motifs in monoheme cytochromes have shown varying outcomes for physiology, which were generally attributed to the specific cytochrome maturation machinery employed by the cell (3). In Ccm-based maturation (biogenesis system I), monoheme cytochromes usually do not mature if one of the cysteines in the $\mathrm{CXXCH}$ motif is replaced $(3,30)$. Generally, the physiological effects of a cysteine mutation in $\mathrm{CXXCH}$ often eliminate the particular respiration in mutant backgrounds. However, the physiological outcomes of single cysteine mutations in $\mathrm{CXXCH}$ in multiheme cytochromes are not well studied. In the Wolinella succinogenes nitrite reductase, $\mathrm{NrfH}$, seven out of eight individual cysteine replacements resulted in elimination of nitrite respiration (33). Interestingly, one of the heme mutants $(\mathrm{C} 66 \mathrm{~S})$ contained a heme covalently linked to the apocytochrome. This was attributed to the function of cytochrome biogenesis system II, which is present in several gram-positive bacteria and several epsilon-proteobacteria, including Wolinella succinogenes. Mutations to the histidine in the $\mathrm{CXXCH}$ heme binding motifs eliminate heme attachment, which usually eliminates the particular respiration $(5,9)$. In multiheme cytochromes, mutations in either of the cysteine or histidine residues of one $\mathrm{CXXCH}$ motif are likely to affect the structure and conformation of the protein. The absence of one heme could cause distortion in the packing of neighboring hemes, which could lead to secondary effects, such as disrupting a quinone-binding site and/or altering the midpoint potentials of the remaining hemes. It is doubtful that the Ccm biogenesis system (type I) of Shewanella can still attach hemes to variants of CymA containing single cysteine-to-serine mutations (italic) in the heme $c$ binding motif $(S X X C H$ or $\mathrm{CXXSH}$ ). However, the unaltered $\mathrm{CXXCH}$ motifs in CymA may still contain covalently linked hemes. Further investigations should uncover these molecular details.

The interactions of CymA with ArrAB most likely extend to other terminal reductases (e.g., periplasmic nitrate and fumarate reductases). Such interactions may require conserved domains on both CymA and the cognate redox partner of the terminal reductase. Whether these same interactions and domains occur among similar terminal reductases in non-arsenate-respiring Shewanella species strains (e.g., ANA-3 versus MR-1) and more broadly in arsenate-respiring non-Shewanella prokaryotes remains unknown. The conservation of CymA at the sequence and molecular levels (Fig. 2) and its physiological role in anaerobic respiration suggest that Shewanella has evolved to streamline a number of respiratory pathways by simplifying the branching point of the electron transport chain. The origin of CymA and its mechanisms of interaction with other redox partners are largely unknown.

\section{ACKNOWLEDGMENTS}

We thank the three anonymous reviewers for their constructive comments on the manuscript during the review process. We also thank Jizhong Zhou at the University of Oklahoma for providing us with Shewanella sp. strain W3-18-1.

\section{REFERENCES}

1. Afkar, E., J. Lisak, C. Saltikov, P. Basu, R. S. Oremland, and J. F. Stolz. 2003. The respiratory arsenate reductase from Bacillus selenitireducens strain MLS10. FEMS Microbiol. Lett. 226:107-112.

2. Ahmann, D., L. R. Krumholz, H. F. Hemond, D. R. Lovley, and F. M. Morel. 1997. Microbial mobilization of arsenic from sediments of the Aberjona watershed. Environ. Sci. Technol. 31:2923-2930.

3. Allen, J. W., and S. J. Ferguson. 2006. What is the substrate specificity of the System I cytochrome $c$ biogenesis apparatus? Biochem. Soc. Trans. 34:150151.

4. Appelo, C. A., M. J. Van Der Weiden, C. Tournassat, and L. Charlet. 2002. Surface complexation of ferrous iron and carbonate on ferrihydrite and the mobilization of arsenic. Environ. Sci. Technol. 36:3096-3103.

5. Cartron, M. L., M. D. Roldan, S. J. Ferguson, B. C. Berks, and D. J. Richardson. 2002. Identification of two domains and distal histidine ligands to the four haems in the bacterial c-type cytochrome NapC; the prototype connector between quinol/quinone and periplasmic oxido-reductases. Biochem. J. 368:425-432.

6. Dietrich, W., and O. Klimmek. 2002. The function of methyl-menaquinone-6 and polysulfide reductase membrane anchor (PsrC) in polysulfide respiration of Wolinella succinogenes. Eur. J. Biochem. 269:1086-1095.

7. Field, S. J., P. S. Dobbin, M. R. Cheesman, N. J. Watmough, A. J. Thomson, and D. J. Richardson. 2000. Purification and magneto-optical spectroscopic characterization of cytoplasmic membrane and outer membrane multiheme c-type cytochromes from Shewanella frigidimarina NCIMB400. J. Biol. Chem. 275:8515-8522.

8. Fredrickson, J. K., J. M. Zachara, D. W. Kennedy, H. L. Dong, T. C. Onstott, N. W. Hinman, and S. M. Li. 1998. Biogenic iron mineralization accompanying the dissimilatory reduction of hydrous ferric oxide by a groundwater bacterium. Geochim. Cosmochim. Acta 62:3239-3257.

9. Gross, R., R. Eichler, and J. Simon. 2005. Site-directed modifications indicate differences in axial haem c iron ligation between the related $\mathrm{NrfH}$ and NapC families of multihaem c-type cytochromes. Biochem. J. 390:689-693.

10. Harvey, C. F., C. H. Swartz, A. B. Badruzzaman, N. Keon-Blute, W. Yu, M. A. Ali, J. Jay, R. Beckie, V. Niedan, D. Brabander, P. M. Oates, K. N. Ashfaque, S. Islam, H. F. Hemond, and M. F. Ahmed. 2002. Arsenic mobility and groundwater extraction in Bangladesh. Science 298:1602-1606.

11. Islam, F. S., A. G. Gault, C. Boothman, D. A. Polya, J. M. Charnock, D. Chatterjee, and J. R. Lloyd. 2004. Role of metal-reducing bacteria in arsenic release from Bengal delta sediments. Nature 430:68-71.

12. Kneebone, P. E., P. A. O'Day, N. Jones, and J. G. Hering. 2002. Deposition and fate of arsenic in iron- and arsenic-enriched reservoir sediments. Environ. Sci. Technol. 36:381-386.

13. Kostka, J., and K. H. Nealson. 1998. Isolation, cultivation and characterization of iron- and manganese-reducing bacteria, p. 58-78. In R. S. Burlage, R. Atlas, D. Stahl, G. Geesey, and G. Sayler (ed.), Techniques in microbial ecology. Oxford, New York, NY.

14. Kovach, M. E., R. W. Phillips, P. H. Elzer, R. M. Roop, and K. M. Peterson. 1994. pBBR1MCS - a broad-host-range cloning vector. BioTechniques 16: 800 .

15. Krafft, T., and J. M. Macy. 1998. Purification and characterization of the respiratory arsenate reductase of Chrysiogenes arsenatis. Eur. J. Biochem. 255:647-653.

16. Macy, J. M., J. M. Santini, B. V. Pauling, A. H. O'Neill, and L. I. Sly. 2000. Two new arsenate/sulfate-reducing bacteria: mechanisms of arsenate reduction. Arch. Microbiol. 173:49-57.

17. Malasarn, D., C. W. Saltikov, K. M. Campbell, J. M. Santini, J. G. Hering, and D. K. Newman. 2004. arrA is a reliable marker for As(V) respiration. Science 306: 455 .

18. McEwan, A. G., J. P. Ridge, C. A. Mcdevitt, and P. Hugenholtz. 2002. The DMSO reductase family of microbial molybdenum enzymes; molecular properties and role in the dissimilatory reduction of toxic elements. Geomicrobiol. J. 19:3-21.

19. Murray, A. E., D. Lies, G. Li, K. Nealson, J. Zhou, and J. M. Tiedje. 2001. DNA/DNA hybridization to microarrays reveals gene-specific differences between closely related microbial genomes. Proc. Natl. Acad. Sci. USA 98:9853-9858.

20. Myers, C. R., and J. M. Myers. 1997. Cloning and sequence of cymA, a gene encoding a tetraheme cytochrome $c$ required for reduction of iron(III), 
fumarate, and nitrate by Shewanella putrefaciens MR-1. J. Bacteriol. 179: $1143-1152$.

21. Myers, C. R., and J. M. Myers. 1992. Localization of cytochromes to the outer membrane of anaerobically grown Shewanella putrefaciens MR-1. J. Bacteriol. 174:3429-3438.

22. Myers, C. R., and J. M. Myers. 1997. Outer membrane cytochromes of Shewanella putrefaciens MR-1: spectral analysis, and purification of the 83$\mathrm{kDa} c$-type cytochrome. Biochim. Biophys. Acta 1326:307-318.

23. Myers, J. M., and C. R. Myers. 2000. Role of the tetraheme cytochrome CymA in anaerobic electron transport in cells of Shewanella putrefaciens MR-1 with normal levels of menaquinone. J. Bacteriol. 182:67-75.

24. Oremland, R. S., and J. F. Stolz. 2005. Arsenic, microbes and contaminated aquifers. Trends Microbiol. 13:45-49.

25. Oremland, R. S., and J. F. Stolz. 2003. The ecology of arsenic. Science 300:939-944.

26. Roldan, M. D., H. J. Sears, M. R. Cheesman, S. J. Ferguson, A. J. Thomson, B. C. Berks, and D. J. Richardson. 1998. Spectroscopic characterization of a novel multiheme $c$-type cytochrome widely implicated in bacterial electron transport. J. Biol. Chem. 273:28785-28790.

27. Saltikov, C. W., A. Cifuentes, K. Venkateswaran, and D. K. Newman. 2003. The ars detoxification system is advantageous but not required for $\mathrm{As}(\mathrm{V})$ respiration by the genetically tractable Shewanella species, strain ANA-3. Appl. Environ. Microbiol. 69:2800-2809.
28. Saltikov, C. W., and D. K. Newman. 2003. Genetic identification of a respiratory arsenate reductase. Proc. Natl. Acad. Sci. USA 100:10983-10988.

29. Saltikov, C. W., R. A. Wildman, Jr., and D. K. Newman. 2005. Expression dynamics of arsenic respiration and detoxification in Shewanella sp. strain ANA-3. J. Bacteriol. 187:7390-7396.

30. Sambongi, Y., R. Stoll, and S. J. Ferguson. 1996. Alteration of haem-attachment and signal-cleavage sites for Paracoccus denitrificans cytochrome C550 probes pathway of $c$-type cytochrome biogenesis in Escherichia coli. Mol. Microbiol. 19:1193-1204.

31. Sambrook, J., E. F. Fritsch, and T. Maniatis. 1989. Molecular cloning: a laboratory manual, 2nd ed. Cold Spring Harbor Laboratory Press, Cold Spring Harbor, NY.

32. Schwalb, C., S. K. Chapman, and G. A. Reid. 2003. The tetraheme cytochrome CymA is required for anaerobic respiration with dimethyl sulfoxide and nitrite in Shewanella oneidensis. Biochemistry 42:9491-9497.

33. Simon, J., R. Eichler, R. Pisa, S. Biel, and R. Gross. 2002. Modification of heme $c$ binding motifs in the small subunit $(\mathrm{NrfH})$ of the Wolinella succinogenes cytochrome $c$ nitrite reductase complex. FEBS Lett. 522:83-87.

34. Zachara, J. M., J. K. Fredrickson, S. M. Li, D. W. Kennedy, S. C. Smith, an P. L. Gassman. 1998. Bacterial reduction of crystalline $\mathrm{Fe} 3+$ oxides in single phase suspensions and subsurface materials. Am. Mineral. 83:1426-1443.

35. Zobrist, J., P. R. Dowdle, J. A. Davis, and R. S. Oremland. 2000. Mobilization of arsenite by dissimilatory reduction of adsorbed arsenate. Environ. Sci. Technol. 34:4747-4753. 